\title{
Recommendations for Weakened Teeth Submitted to Fixed Restorations
}

\section{Khiari $\mathrm{A}^{* 1}$, Hadyaoui $\mathrm{D}^{2}$ and Cherif $\mathrm{M}^{2}$}

${ }^{1}$ Department of fixed prosthodontics, Faculty of dental medicine, Monastir, Tunisia

${ }^{2}$ Phylosophic Doctor, Department of fixed prosthodontics, University of dental medicine, Monastir, Tunisia

*Corresponding author: Khiari A, Department of fixed prosthodontics, Faculty of dental medicine, Monastir, Tunisia, Tel: +216 559678 60, +216986763 49, E-mail: amina_khiari@hotmail.fr

Citation: Khiari A, Hadyaoui D, Cherif M (2016) Recommendations for Weakened Teeth Submitted to Fixed Restorations. J Dent Oral Care Med 2(1): 101. doi: 10.15744/2454-3276.2.101

Received Date: October 13, 2015 Accepted Date: February 05, 2016 Published Date: February 08, 2016

\begin{abstract}
Weakened teeth are varied in terms of causes and effects. The most common etiology of dental tissue loss is dental caries leading to endodontic treatment. This can cause an enormous esthetic problem because of the subsequent discoloration of the weakened tooth. Knowledge regarding the clinical complications enhances clinicians to complete a thorough clinical examination and diagnosis, and thus to develop the appropriate treatment satisfying the esthetic expectations of the patient. In this short communication, we discuss different therapeutic modalities (endodontic treatment, internal bleaching, fiber reinforced reconstruction, and fixed restorations) which have to be associated to enhance biological, functional and mainly esthetic outcome of final fixed restorations.

Keywords: Dental caries; Endodontic treatment; Bleaching; Fiber reinforced post and core reconstruction; Prosthesis
\end{abstract}

\section{Short communication}

The primary factors for loss of tooth structure include dental caries, endodontic access preparation, and root canal preparation. In fact, after preparation of mesial occlusal distal (MOD) cavities, the fracture strengths of teeth were reduced to approximately 54\% of their original strength. Although, the reduction of fracture resistance and hardness of teeth are generally the main consequences of endodontic treatment. This latter cannot cause deshydratation and brittleness after root canal treatment [1]. On the other hand, intracoronal whitening is highly recommended for discolored teeth treated endodontically [2]. While studies on the effects of bleaching on morphological changes to dental tissue are contradictory, some of them have confirmed the responsibility of bleaching agents for reducing the reducing the fracture resistance of tooth and inducing its fracture [2,3]. Researches showed ion release from both enamel and dentin after bleaching with different concentration of hydrogen peroxide, others demonstrated lowered phosphorus and calcium levels with a decrease of the mean $\mathrm{Ca} / \mathrm{P}$ value after bleaching with $10 \%$ of carbamide peroxide [3]. However, Rotstein et al. [4] studied the effects of sodium perborate mixed with water on the modifications of chemical elements of tooth, and showed that the sulfur level included on the cementum was reduced. This proved that the organic composition was damaged. In opposite to many studies, the concentrations of phosphorus and calcium were maintained, indicating that the inorganic component was not affected. To conclude, Maleknejed, et al. [3] proved that the diameter of dentinal tubule were increased by all bleaching agents which foster alterations of the mineral composition of dentin, with the exception of sodium perborate mixed with water.

With the presence of weakened and endodontically restored tooth, posts are needed to allow the clinician to rebuild enough tooth structure to retain restoration [5]. Therefore, Salameh, et al. [1] suggested the necessity of fiber posts placement in the root canal and thus to enhance mechanical behavior of the tooth even under full-coverage crowns. From a technical point of view and compared with metallic posts, it was claimed that, due to similar elasticity, less stress is transferred from fiber reinforced composite post (FRCP) to dentin, which would reduce the concentration of load on root dentin. Moreover, repairable fractures were noted with endodontically treated teeth which were filled with FRCPs [6].

It is recommended to restore weakened tooth treated endodontically with fixed prostheses, as proved by Stavropoulou, et al. [7] who reported that endodontically treated teeth restored with single crowns showed a long-term survival rate in comparison with direct restoration which have an acceptable short-term survival rate. Likewise, root canal treated teeth restored with single crowns and implant supported single crowns showed similar long-term survival rates, which were superior to the survival rate of bridges.

\section{References}

1. Salameh Z, Sorrentino R, Ounsi HF, Goracci C, Tashkandi E, et al. (2007) Effect of different all-ceramic crown system on fracture resistance and failure pattern of endodontically treated maxillary premolars restored with and without glass fiber posts. J Endod 33: 848-51.

2. Roberto AR, Sousa-Neto MD, Viapiana R, Giovani AR, Souza Filho CB, et al. (2012) Effect of different restorative procedures on the fracture resistance of teeth submitted to internal bleaching. Braz Oral Res 26: 77-82. 
3. Maleknejad F, Ameri H, Kianfar I (2012) Effect of intracoronal bleaching agents on ultrastructure and mineral content of dentin. J Conserv Dent 15: 174-7.

4. Rotstein I, Dankner E, Goldman A, Heling I, Stabholz A, et al. (1996) Histochemical analysis of dental hard tissues following bleaching. J Endod 22: $23-5$.

5. Akkayan B, Gülmez T (2002) Resistance to fracture of endodontically treated teeth restored with different post systems. J Prosthet Dent 87: 431-7.

6. Cauwels RG, Lassila LV, Martens LC, Vallittu PK, Verbeeck RM, et al. (2014) Fracture resistance of endodontically restored, weakened incisors. Dent Traumatol 30: 348-55.

7. Stavropoulou AF, Koidis PT (2007) A systematic review of single crowns on endodontically treated teeth. J Dent 35: 761-7.

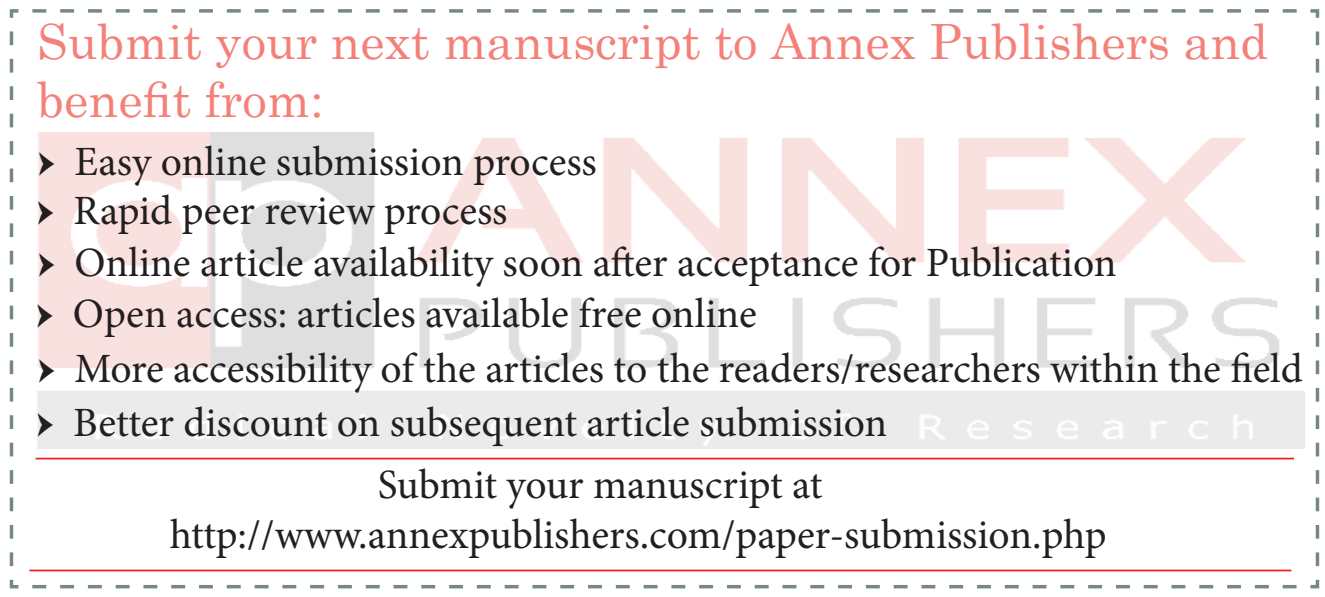

